\title{
Project Citizen Model's Effect on Students' Learning Interest in Civic Education as an Embodiment of Character Education
}

\author{
Maryatun Kabatiah', Irwan'2, Firman ${ }^{3}$ \\ ${ }^{1}$ Pancasila and Civic Education Department, Faculty of Social Sciences, Universitas Negeri Medan, \\ Indonesia \\ 2Pancasila and Civic Education Department, Faculty of Teacher Training and Education Sciences, \\ Universitas Jambi, Indonesia \\ ${ }^{3}$ Economic Education Department, Faculty of Teacher Training and Education Sciences, Universitas \\ Jambi, Indonesia \\ 1maryatunkabatiah@unimed.ac.id
}

\begin{abstract}
Civic Education is one of the courses that carry the mission of character education. Compared to other courses, Civic Education course play an important role in teaching character education, meaning that in both courses, character education must be the lecture's main goal. Civic education is a field of study that carries out the national mission to educate Indonesian people through value-based education. One of the adaptive models in improving the quality of civic education as a manifestation of character building is through Project Citizen. This study aims to determine the effect of project citizen model in the learning interest of students of the Faculty of Teacher Training and Education Sciences (FKIP) University of Jambi (UNJA) in learning civic education as an embodiment of character education. The type of research is an experimental research which is used in Pre-Experimental Design using the Intact Group Comparison draft. In this design, one group of study was divided into a treatment group and a non-treatment group. The population of the study was all of FKIP UNJA students, while the sample was students of class A of the Department of Early Childhood Education (PAUD). The research instrument used was a learning interest questionnaire with questions and statements measured using a Likert scale. The data was then analyzed by the T-test using SPSS 21 software for Windows. Based on the result, it can be concluded that the project citizen model has a significant effect on FKIP UNJA students' learning interest in learning civic education as an embodiment of character education.
\end{abstract}

Keywords: project citizens, Civic Education Course, character education

\begin{abstract}
ABSTRAK
Pendidikan Kewarganegaraan (PKn) merupakan salah satu mata kuliah yang mengemban misi pendidikan karakter. Dibandingkan dengan mata kuliah lain, mata kuliah PKn memiliki posisi sebagai ujung tombak dalam pendidikan karakter. Hal ini berarti bahwa dalam kedua mata kuliah tersebut pendidikan karakter harus menjadi tujuan perkuliahan. PKn merupakan salah satu bidang kajian yang mengemban misi nasional untuk mencerdaskan kehidupan bangsa Indonesia melalui koridor "value-based education". Salah satu model yang digunakan untuk meningkatkan kualitas PKn sebagai perwujudan pembangunan karakter adalah melalui Project Citizen. Penelitian ini bertujuan untuk mengetahui pengaruh model project citizen terhadap minat belajar mahasiswa Fakultas Keguruan dan Ilmu Pendidikan (FKIP) Universitas Jambi (UNJA) dalam pembelajaran PKn sebagai bentuk pendidikan karakter. Jenis penelitian ini adalah penelitian eksperimen yang termasuk dalam Pre-Exsperimental Design dengan menggunakan rancangan Intact Group Comparison. Pada desain ini terdapat satu kelompok yang dibagi dua, yaitu setengah kelompok yang diberi perlakuan dan setengah
\end{abstract}


kelompok yang tidak diberi perlakuan. Populasi penelitian ini adalah seluruh mahasiswa FKIP UNJA, sedangkan sampel penelitian ini adalah mahasiswa Jurusan Pendidikan Anak Usia Dini (PAUD) kelas A. Instrumen penelitian yang digunakan adalah angket minat belajar dengan pertanyaan dan pernyataan diukur menggunakan Skala Likert. Data dianalisis menggunakan uji T dengan SPSS 21 for Windows. Berdasarkan hasil penelitian yang dilakukan, dapat disimpulkan bahwa model project citizen berpengaruh signifikan terhadap minat belajar mahasiswa FKIP UNJA dalam pembelajaran PKn sebagai wujud pendidikan karakter.

Kata kunci: project citizen, Mata Kuliah Pendidikan Kewarganegaraan, pendidikan karakter

This work is licensed under the Creative Commons Attribution-ShareAlike 4.0 International License. (2021 by the author(s).

\section{INTRODUCTION}

Civic Education is one of the courses that carry the mission of character education. Compared to other courses, Civic Education and Religion courses play an important role in implementing character education. This means that in both courses character education must be the goal of the lecture. Civic Education has a mission to educate the Indonesian people through the corridor of "values-based education" (Budimansyah \& Winataputra, 2007). The development of national character is an important thing in order to maintain the existence of the state and the nation. Character is a set of good qualities which becomes daily behavior as the manifestation of the awareness about someone's roles and duties in the society, as outlined in the Article 3 in the Act of the Republic of Indonesia Number 20 Year 2003 on the National Education System, "the national education functions to develop the capabilities, character, and civilization of the nation... imbued with human values who are faithful and pious to one and only God; who possess morals and noble character; who are healthy, knowledgeable, competent, creative, independent, and as citizens, are democratic and responsible." Character values are solid roots in supporting the integrity of the nation and the state. The weakening of character values in people's lives is an indication of the collapse of a nation. The development of morals is closely related to the fostering and development of values starting from the smallest social unit, namely the family, to the largest environment of schools and communities. Therefore, character in education is something that cannot be avoided.

As a home for character education, Civic Education will provide its own characteristics for students if presented with an appropriate and effective learning model. It is also expected to strengthen the values of unity and togetherness which forms a strong and quality nation as well as the Indonesian characters. However, if it is presented in an inappropriate way, it will reduce the students' interest in exploring the courses. One adaptive learning model that is currently developed in Indonesia is a model of citizenship learning practice commonly called "Project Citizen" in which there is a portfolio of student learning outcomes. As a problembased instructional treatment, the project citizen functions to develop democratic knowledge, skills and characters of the citizens. The project citizen is one of the potential models for conducting character-based learning that is believed to be able 
to transform values to students (Budimansyah, et al, 2010). Project citizen models improve significantly citizenship skills because this model provides opportunities for students to practice critical thinking, interact and discuss with classmates, negotiate, collaborate and make the best decisions for the public interest (Atherton, 2000; Vontz, et.al ,2000; Trisiana, 2015). The project citizen model is seen as being able to improve students' civic skills well when learning inside and outside the classroom. The project citizen learning model is a learning innovation in the world of education that is quite suitable to be applied in the subjects of citizenship education because it is useful to equip students in daily life and solving a problem (Adha, et.al, 2018)

This study aims to describe the effect of project citizen model on the learning interest of FKIP UNJA students in learning civic education as an embodiment for character education. A practical-empirical learning model based on problem-solving from project citizen uses learning principles that start from students' interest. This can be seen from the first step of learning is to identify problems that are carried out by students themselves, based on their respective interests.

\section{RESEARCH METHOD}

This type of research is experimental, specifically the Pre-Experimental Design using the Intact Group Comparison draft. In this design, one sample group was studied and divided into two. Therefore, half the group was treated and the other half was untreated (Sugiyono, 2010).

The population of this study was all students of FKIP UNJA, where the researcher team were assigned to teach. The sample of this study was the class A students of Early Childhood Education (PAUD) major. The research instrument used was a questionnaire about students' learning interest with questions and statements measured using the Likert scale. Data were analyzed using the T-test with SPSS 21 for Windows.

\section{RESULTS AND DISCUSSION}

One of the courses that carries the mission of character education is civic education. Civic education is expected to be a psychological-pedagogical setting to internalize the characters of Pancasila among Indonesian citizens (Winataputra, 2015). Character Education that has been proclaimed as a national movement in 2010 turned out to be not effective enough. Therefore, character education is echoed and strengthened again as the National Character Education Movement through the national Character Education Strengthening Program in 2016. The Ministry of National Education has also developed a grand design of Character Education in each path, level, and type of educational unit. The follow-up of the policy is the formulation of the five main values of characters that are interconnected to be developed as a priority for the Character Education Strengthening Program. The five main values are; (1) religious, (2) nationalists, (3) independent, (4) mutual cooperation, and (5) integrity.

As an educational program that is very strategic for character education, Civics needs to strengthen its position to become a "powerful learning area", which 
is characterized by contextual learning experiences with the characteristics of meaningful, integrated, value-based, challenging, and activating. It is through such learning experiences that students are facilitated to be able to build knowledge, attitudes, and skills of democratic citizenship in the psycho-pedagogical-constructive corridor. Civic education's systemic configuration or framework is built on the basis of the following paradigm. First, civic education curriculum is designed to include learning subjects that include developing the potential to become noble, intelligent, participatory, and morally responsible citizens. Second, civic education is theoretically designed as a learning subject that contains cognitive, affective, and psychomotor dimensions that are confluent and integrated with ideas, values, concepts, and morals of Pancasila, democratic citizenship, and state defense. Third, civic education is programmatically designed as a learning subject that emphasizes value embedded contents and learning experiences in the form of various behaviors that need to be manifested in everyday life as a further elaboration of ideas, values, the concept and moral of Pancasila, democratic citizenship, and state defense (Budimansyah \& Winataputra, 2007).

As a center for character education, civic education is not just transmitting the contents of certain values to students but is interpreted as an effort to develop an assessment process in a person, a kind of belief to enrich students with something more crucial and functional. One of the adaptive models to improve the quality of civics learning as a setting for character education is through the Project Citizen model. Previous research found that the implementation of the project citizen in civic education learning was able to significantly improve citizenship skills. Project citizen model is very suitable to be applied in civic education subjects, because civics subjects facilitate the forming of citizens of intelligence, skills and good character. Therefore, it is worth checking out whether project citizen models can be applied to strengthen character education in the learning of civic education (Jayadiputra, 2015).

There are three stages that need to be done in character learning, namely: identification of values, learning values, and providing opportunities to apply these values. The emphasis of this learning package is the involvement of students in the whole process, and with that process, students are facilitated to gain knowledge, attitudes, and skills. In its implementation, the learning package "We the People... Project Citizen" (CCE, 1998) is packaged in a procedure and learning signs that include the following six steps:

(1) Identifying public policy problems in the society.

In this step, the class is facilitated to be able to identify various problems in the community through observations, interviews, and documentation studies, which are conducted in groups. The purpose of this stage is for the students to share and exchange information they already know. Therefore, the group will obtain sufficient information that can be used to select the most suitable problem among several existing problems as the material for the group study.

(2) Selecting the problems as the focus of classroom studies.

In this step, the class is facilitated to examine the various problems and then select the one most feasible to solve. The selection can be done in private, for example, each student writes his/her choice on a piece of paper and then folds it and 
gives them to the lecturer. In order to provide more experience for students in holding class elections, lecturers may arrange some sort of committee that includes for example a chairman, secretary, and witness for the purpose of vote counting.

(3) Gathering information related to the problem that is the focus of the classroom study.

In this step, the class is facilitated to collect the necessary information in order to solve the problem from various relevant and available information sources, such as libraries, mass media, professionals and experts, government officials, nongovernmental organizations, as well as community leaders and members. Activities in step three provide a lot of learning experiences to students, such as getting used to making decisions with the support of accurate data and information, which they obtain when they collect data and information from various sources to answer the problems that are the subject of the group study. This ability is important for good character citizens because there will be dire consequences if decisions are made based only on feelings or even based on irrational considerations. Another thing that is obtained from the learning process in this third step is the ability to communicate. Some of the sources of information come from people, both individuals and groups. Therefore, the more they intensively interact with informants, the smarter the students will be in communicating.

(4) Developing a class portfolio.

In this step, the class develops a portfolio in the form of a collection of group work in solving these problems and presents them as a whole in an exhibition panel that can be seen together to describe the interrelationship of problems, provide policy alternatives, propose support for policy alternatives and action plans for implementing policies.

(5) Presenting the class portfolio in a simulation hearing.

In this step, the entire portfolio that has been developed is then presented and exhibited to the academic community and society. In this fifth step, students learn to communicate ideas to others and learn to convince others to accept their ideas. This activity requires a high level of communication skills because they not only have to master the materials comprehensively but also to understand mass psychology, persuasion techniques, marketing skills, and so on. Besides that, for students who have the potential for linguistic intelligence, this showcase event is a valuable experience to hone their talents and abilities.

(6) Conducting a reflective study of the learning experience undertaken.

In the final step, students return to the class to reflect on the learning outcomes achieved through all these activities. Reflecting on the learning experience is one way to learn, to avoid making mistakes, and to improve the abilities students already have. To enter this stage, students must have completed a group portfolio. As an additional part, students can include the Reflection or Evaluation Section in the Documentation Section Map. Reflections on this experience are the result of a collaboration among groups and group members that has been done during the group portfolio. In addition, students must also reflect on their learning experiences both as individuals and as members of the group.

The results of this study indicate that the project citizen model has a significant effect on increasing students' interest in learning civic education as an 
embodiment of character education. According to Sudaryono (2012), students' interest in learning can be measured through: keenness, interest, attention, and engagements. Students' keenness can be seen from their enthusiasm in studying. Interests can be seen from students' responses in class. Attention can be measured by their seriousness during the learning process. It is also driven by curiosity. Students who are interested on a subject will tend to give greater attention on the material they study. In this study, learning interest were measured using a questionnaire delivered after the application of the project citizen model to the treated group and the conventional model to the untreated group. The result shows that after being given different treatments, students' interest in the treated group was higher than in the untreated group. The questionnaire was based on the indicators of learning interest, namely: a. keenness, b. interest c. attention, and d. engagements, as seen in Table 1.

Table 1. The average result of students' learning interest

\begin{tabular}{lcc}
\hline \multicolumn{1}{c}{ Indicator } & Treated group & Untreated group \\
\hline Keenness & 0,688 & 0,645 \\
Interest & 0,631 & 0,602 \\
Attention & 0,691 & 0,572 \\
Engagements & 0,783 & 0,657 \\
\hline
\end{tabular}

Indicator with the highest value between the two classes was engagement, which was 0.783 in the treated group and 0.657 in the untreated group. The lowest indicator in the treated group was interest, which was 0.631 ; while the lowest in the untreated group was attention, which was 0.572. The interest indicator in the untreated group was 0.572, and in the treated group was 0.691. Meanwhile, the keenness indicator was 0.687 in the untreated group and 0.783 in the treated group. The result of the average students' responses to the learning interest indicator showed that the mean of the treated group was higher than the untreated group.

Based on the normality and the homogeneity test conducted before testing the hypothesis using the T-test, it is concluded that the data is normally distributed with a significance level of 0.200 and both groups are homogenous with the test result of 0.385 and a probability greater than 0.05 . The hypothesis test using the T-test was for two unpaired samples (independent samples T-test).

Furthermore, the result of the analysis was used to test the research hypothesis with a significance level (a) of $5 \%$. Based on the result of the hypothesis test, it can be seen that the Sig. (2- tailed) is $0.056 / 2=0.028$, which is smaller than 0.05. This means that there is a significant difference in students' civic education learning interest between the untreated group and the treated group. Hypothesis testing was seen from the significant value of the treated group and untreated group, so it can be concluded that there is an effect of the project citizen model on FKIP UNJA students' learning interest in civic education learning as an implementation for character education. 
Therefore, the project citizen model is effective among FKIP UNJA students. The model is very supportive of civic education, which is one of the fields of study that carries out a national mission to educate the Indonesian people through the corridor of "value-based education". Budimansyah $(2008,2009)$ explains that the most important and interesting data and information is when the data and information are attached to the display portfolio section, which is a panel board made of used cardboard or other available material. After the portfolio is completed, a public hearing is held in the showcase activity before the jury. The showcase activity is the peak performance of students, because at this stage, the results of student work will be tested and debated before the jury. The last stage of project citizen is to reflect on the learning experience of the whole group. The objectives of using the project citizen model in civics learning in universities are in order for the learning to: 1) become more meaningful, 2) become more integrated. 3) allow more value basis, 4) become more challenging, 5) use an active learning approach.

\section{CONCLUSION}

Based on the analysis of students' responses to the learning interest indicators, it can be concluded that the project citizen model is effective among FKIP UNJA students, as seen from the higher average score of indicators of students from the treated group compared with those of students from the untreated group. The highest indicator of the two classes was the engagement indicator, while the lowest indicator in the treated group was the interest indicator, and the lowest in the untreated group was the attention indicator. Furthermore, the results of hypothesis testing means that there is a significant difference in students' civic education learning interest between the untreated group and the treated group. Hypothesis testing was seen from the significant value of the treated group and untreated group, so it can be concluded that there is an effect of the project citizen model on the interest of FKIP UNJA students in learning civic education. Based on this conclusion, we recommend further experiments on project citizen model in other campuses and detailed evaluation on the learning process using the project citizen model.

\section{REFERENCES}

Adha, M.M., Hermi, Y., \& Yunisca, N. (2018). The Improvement of Student Intelectual and Participatory Skill Through Project Citizen Model in Civic Education Classroom. International Journal Pedagogy of Social Studies, 3 (1), 2018, 39-50

Atherton, H. M. (2000). We the people ... project citizen. (Ed), Mann, S. \&Patrick, J. J. Education for civic engagement in democracy: Service learning and other promising practices. Indiana: ERIC Clearinghouse for social studies/social science education.

Budimansyah, D dan Winataputra U.S. (2007). Civic Education 'Konteks,Landasan, Bahan Ajar, Dan Kultur Kelas. Bandung: Program Studi Pendidikan Kewarganegaraan Sekolah Pasca Sarjana UPI.

Budimansyah, D. (2008). Revitalisasi Pembelajaran Pendidikan Kewarganegaraan Melalui Praktik Belajar Kewarganegaraan (Project Citizen). Acta Civicus, 1(2), 184.

Budimansyah, D. (2009). Inovasi Pembelajaran Project Citizen.Bandung: Program Studi PKn SPs UPI. 
Budimansyah, D, Ruyadi, Y., \& Rusmana, N. (2010). Model Penguatan Karakter di Perguruan Tinggi. Bandung: Universitas Pendidikan Indonesia.

CCE. (1998). We the People ...Project Citizen: Teacher Guide. Calabasas: CCE.

Jayadiputra. (2015). Model Project Citizen Dalam pembelajaran PKn. CISOC, 2(1), 102

Sudaryono. (2012). Dasar-dasar Evaluasi Pembelajaran. Yogyakarta: Graha Ilmu

Sugiyono.(2010). Metode Penelitian kuantitatif,kualitatif dan RED. Bandung: Alfabheta.

Trisiana, A. (2015). Action for citizenship education of character education using project citizen model at senior high school in Indonesia. International Journal of Education and Psychology in the Community, 5(1\&2), 42-53.

Undang-Undang Republik Indonesia Nomor 20 Tahun 2003 tentang Sistem Pendidikan Nasional. (n.d.).

Vontz, T. S., Metcalf, K. K., \& Patrick, J. J.(2000). Project Citizen and the Civic Development of Adolescent Students in Indiana, Latvia, and Lithuania. Indiana: Indiana University ERIC, Educational Resources Information Center.

Winataputra, U. S. (2015). Pendidikan Kewarganegaraan: Refleksi Historis-Epistemologis dan Rekonstruksi untuk Masa Depan. Tangerang Selatan: Universitas Terbuka. 